\title{
I mpact of maize storage on rural household food security in Northern Kwazulu-Natal ${ }^{1}$
}

\author{
J oyce M Thamaga-Chitja, Sheryl L Hendriks, Gerald F Ortmann, \\ \& Maryann Green
}

\begin{abstract}
OPSOMMING
Die bevindinge van 'n studie wat die invloed van die effektiwiteit van die berging van mielies (tydsduur van berging en verliese) op huishoudelike voedselsekuriteit in 134 landelike huishoudings in noordelike Kwa-Zulu-Natal (1999) ondersoek het, word gerapporteer. Die huishoudings wat in die steekproef opgeneem is, is uit drie distrikskleinboere organisasies getrek. Onderhoude is gevoer aan die hand van ' $\mathrm{n}$ semi gestruktureerde vraelys. Mielie bergingsmetodes is verder ondersoek in fokus groep besprekings. Die bevindinge dui daarop dat berging van mielies oneffektief is en dat dit nie die huishouding se voedselsekuriteit betekenisvol verbeter het nie. Aanbevelings sluit in opleiding betreffende die berging van mielies, verbeteringe aan die populêre nqolobane, die gebruik van meer doeltreffende plaagdoders en ook dat boere geld bymekaar sit om metaal tenks aan te skaf vir beter gesamentlike berging van mielies.
\end{abstract}

\section{- Ms Joyce M Thamaga-Chitja \\ Community Resources \\ Faculty of Science and Agriculture \\ University of KwaZulu-Natal}

\section{- Dr Sheryl L Hendriks}

Food Security Programme

Faculty of Science and Agriculture

University of KwaZulu-Natal

\section{- Prof Gerald F Ortmann}

Agricultural Economics

Faculty of Science and Agriculture

University of KwaZulu-Natal

\section{- Prof J Maryann Green}

Community Resources

Faculty of Science and Agriculture

University of KwaZulu-Natal

${ }^{1}$ The Agrarian Rural Development Programme (ARDP)/ National Research Foundation is thanked for funding this study. The opinions expressed are those of the authors and not necessarily those of the funders.

\section{INTRODUCTION}

Crop storage plays an integral part in ensuring domestic food supply. Despite adequate national food supply, at least 30 percent of South Africa's population experience food insecurity (Bonti-Ankomah, 2001), vis the inability to access enough food at all times to ensure a healthy active life (World Bank, 1986: 1). The incidence of hunger is high among rural South African households (Labadarios, 2000:4-5). Transient hunger is partly attributed to seasonal production, especially of staple crops (maize in the case of KwaZulu-Natal). Effective storage plays an important role in stabilising food supply at the household level by smoothing seasonal food production. However, despite significant advances in food storage methods, many African and South African communities still rely on traditional storage methods for food, fodder and seed. Although relatively simple and inexpensive to construct and maintain, traditional storage systems lead to substantial post-harvest losses (Mughogho, 1989:31-36). Inadequate post-harvest storage contributes significantly to food insecurity and more so in areas with high humidity as is experienced in KwaZulu-Natal (Ntlokwana, 1999).

Storage facilities not only offer the opportunity to smooth hunger between staple crop harvests but farmers are possibly able to improve farm incomes by storing crops and selling at premium prices when demand outstrips supply later in the post-harvest period (Florkowski \& Xi-Ling, 1990). As quality is an important determination of crop retail prices (Kohl \& Uhl, 1998: 24), effective storage is crucial to improve agricultural incomes and food security for small scale farmers. Crop storage efficiency depends on storage length, losses during storage (including quality deterioration) and storage volume. Losses are largely due to disease, pests and oxidative damage (Salunke \& Desai, 1986:8-12). Therefore, air-tight storage is important (Lindbland \& Druben 1980). For storage to be effective, crop losses must be minimised (Takavarasha \& Rukovo, 1989:63-72). The widespread and continued use of traditional storage practices by South Africa's small scale and subsistence farmers despite considerable losses, warrants investigation with respect to improved storage and finding appropriate, efficient and inexpensive post-harvest technologies for small scale farmers.

This paper reports the findings of a study conducted in 1999 to investigate the efficiency of maize storage practices employed by a sample of 134 small scale farmers from three communal areas of KwaZulu-Natal 
and the impact of these storage systems on household food security. The following section of this paper is divided into three sections. The first section includes the methodology followed by sample characteristics. The second section presents and discusses the results of the study which include the maize storage practices of the sample households, an analysis of the efficiency of storage and a description of their food security status (as inferred by nine selected indicators). Finally, conclusions and recommendations are presented.

\section{METHODOLOGY}

A random sample of 134 farmers was selected from membership lists of District Farmers' Unions from three districts in northern KwaZulu-Natal, namely Ubombo, Hlabisa and Ngwavuma. Interviews were conducted with the sample farmers between April and July 1999. An interview schedule (a semi-structured questionnaire) was used to collect information regarding household demographics, farm sizes, agricultural activities, harvests, storage volumes and losses ${ }^{2}$, and household food security information. Nine food security indicators (Table 1 ) were selected from a review of the literature. The nine selected food security indicators were chosen because they had been used previously were relevant, cost effective and the information pertaining to them was readily available. (for examples see: Maxwell \& Frankenberger 1996: 84-102; Maxwell 1996; Haddad et al, 1994; Alderman 1993: 193-201).

In addition to the questionnaire, focus group interviews were conducted with extension staff of the KwaZulu-Natal Department of A Agriculture in each of the three districts to provide in-depth qualitative information of storage methods. An average of eight staff from each district participated in these discussions, accounting for $90 \%$ of the extension officers employed in the districts. The age of the officers ranged from 28 to 40 years. Each participating officer had worked in their district for at least four years and had tertiary level qualifications in various aspects of agriculture.

Data analysis included frequency counts, examination of descriptive statistics, Chi-square tests and cross tabulations to investigate the efficiency of storage systems used by the sample farmers and to determine the influence of maize storage practices on household food security. Sample characteristics are discussed next, followed by the results and discussion of the study.

\section{SAMPLE CHARACTERISTICS}

Agricultural production in the three study districts (Ubombo, Hlabisa and Ngwavuma) was mostly con-

\footnotetext{
2 It was impossible to obtain reliable estimates of the volumes lost in storage as illiteracy and innumeracy levels among the sampled farmers prevented accurate estimations.
}

fined to food production for family use (subsistence farming). Only maize (the principle crop) was stored by the majority $(87 \%)$ of respondent households. Beans, pumpkins, split peas, swiss chard, potatoes, beetroot, sweet potato, green pepper, amadumbe (taro) and peanuts were also grown, but on a much smaller scale than maize. The storage of these crops was not statistically insignificant in relation to household food security. This paper therefore focuses on maize storage practices only. Furthermore, production was predominantly dry-land, larger scale vegetable production was constrained by a lack of irrigation. Farmers lamented the fact that the shortage of productive land in the study areas constrained production and inadequate fencing left maize vulnerable to theft and crop damage by unattended cattle. As production was reportedly inadequate for subsistence, adequate post harvest storage is imperative.

Education levels among sample respondents were low (most had only primary school education). Sample households were characterised by high dependency ratios (average household size of eight) and low incomes (on average R1030 per month per household) (Table 1). The value of household assets was used as a food security indicator (mean household asset value was R4768). Some households declared that they owned none of the itemised assets (i.e. fridge, television, telephone or vehicle).

\section{RESULTS AND DISCUSSION}

The results of the study focused on a description of the maize storage methods used by the sample households, the efficiency of the methods and the influence of maize storage on food security. Conclusion of the findings follow this section.

\section{Maize storage methods}

Maize is traditionally left to dry in the fields prior to harvesting. A high percentage of respondent households (87\%) stored maize. Although sample households typically used a combination of storage methods, the predominant storage method among sample households was the traditional silo (inqolobane), used by 52 percent of sample households (Table 2 ).

The mud and twig inqolobane structure was erected close to homesteads and was relatively inexpensive in terms of materials, but construction required intensive labour input. The size of the structures was reportedly flexible and generally determined by the volume to be stored. Inqolobane were not airtight and often exposed the stored maize to harsh environmental conditions such as sun and rain because of their fallible construction and composition (Figure 1). Holes in the structure were often large enough for rats to access the stored maize, increasing maize losses and compromising the quality and safety of the stored grain. Maize cobs were piled on the floor of the inqolobane while pumpkins were often stored on the structure's roof. 


\begin{tabular}{|l|l|c|c|c|}
\hline \multicolumn{1}{|c|}{ Indicator } & \multicolumn{1}{c|}{ Components of indicator } & Mean & Minimum & Maximum \\
\hline $\begin{array}{l}\text { Monthly income } \\
\text { (Rand/household) }\end{array}$ & Cash in wages, salaries and pensions & 1030.00 & 0.00 & 15000.00 \\
\hline Household size & $\begin{array}{l}\text { Number of adults and children per } \\
\text { household }\end{array}$ & 8.40 & 1.00 & 24.00 \\
\hline $\begin{array}{l}\text { Food expenditure } \\
\text { (Rand/household) }\end{array}$ & $\begin{array}{l}\text { Amount of cash spent on food per } \\
\text { month }\end{array}$ & 389.70 & 0.00 & 2000.00 \\
\hline $\begin{array}{l}\text { Credit expenditure } \\
\text { (Rand/household) }\end{array}$ & $\begin{array}{l}\text { Amount of money paid towards ac- } \\
\text { counts per month }\end{array}$ & 114.90 & 0.00 & 1740.00 \\
\hline $\begin{array}{l}\text { Asset value (Rand/ } \\
\text { household) }\end{array}$ & $\begin{array}{l}\text { Household assets included: fridge, } \\
\text { television, telephone, vehicle. }\end{array}$ & 4768.00 & 0.00 & 69000.00 \\
\hline Age of head (Years) & Age of household head & 52.10 & 22.00 & 78.00 \\
\hline Education level & Education level & 2.00 & 1.00 & 4.00 \\
\hline Land used (Ha) & Amount of land used for farming & 2.50 & 1.00 & 4.00 \\
\hline $\begin{array}{l}\text { Livestock value } \\
\text { (Rand/household) } * *\end{array}$ & $\begin{array}{l}\text { The cash value of livestock per } \\
\text { household }\end{array}$ & 7387.00 & 0.00 & 90000.00 \\
\hline
\end{tabular}

* $\quad$ Education level refers to the highest standard passed by the household head. 1=no education, 2=primary school level, 3=secondary school, 4=tertiary education level.

** Livestock value was calculated as follows: local average price of one head of cattle (R1000) multiplied by the number of cattle. Three goats equaled one head of cattle. Calves were priced on a sliding scale according to their age.

TABLE 2:

RURAL MAIZE STORAGE METHODS, NORTHERN KWAZULU-NATAL, 1999 (N = 134)

\begin{tabular}{|l|c|c|}
\hline Storage method * & Number of households & Percentage of sample households \\
\hline Inqolobane & 69 & 52 \\
\hline Metal tanks & 42 & 31 \\
\hline Sacks & 31 & 23 \\
\hline Roof & 9 & 7 \\
\hline
\end{tabular}

Note: 24 sample households used inqolobane and metal tanks, and four households used inqolobane and sacks for storing maize

TABLE 3: $\quad$ STORAGE EFFICIENCY IN TERMS OF MINIMAL LOSS AND MAIZE STORAGE LENGTH, NORTHERN KWAZULU-NATAL, 1999 ( $\mathrm{N}=134$ )

\begin{tabular}{|l|c|c|c|c|}
\hline $\begin{array}{l}\text { Storage } \\
\text { method }\end{array}$ & $\begin{array}{l}\text { Average storage } \\
\text { length (months) }\end{array}$ & $\begin{array}{l}\text { Minimum storage } \\
\text { length (months) }\end{array}$ & $\begin{array}{l}\text { Maximum storage } \\
\text { length (months) }\end{array}$ & $\begin{array}{l}\text { Households re- } \\
\text { porting loss (\%) }\end{array}$ \\
\hline Inqolobane & 5.6 & 3 & 12 & 85.7 \\
\hline Roof & 8.6 & 6 & 12 & 50.0 \\
\hline Metal tanks & 7.8 & 5 & 24 & 34.8 \\
\hline Sacks & 5.7 & 3 & 24 & 66.7 \\
\hline
\end{tabular}


Forty-two sample households (31\% of sample) used commercially available corrugated iron tanks to store maize in grain form (Figure 2). These tanks stored a comparatively larger volume than inqolobane but require application of commercial insecticides to prevent maize spoilage. However, the sample respondents tightly sealed the lids of the tanks with cow dung. Maize losses during storage were far lower than for traditional methods, although farmers reported that if the lids of the tanks were not well sealed "the tanks would perspire", causing maize rot. The hot and humid weather of northern KwaZulu-Natal aggravated the situation. Grain was reportedly accessed as and when required by households. However, it cannot be ascertained from the information collected if frequent opening of the tanks to draw stock induced maize deterioration. This would need further investigation.

Re-used maize meal sacks were also used to store maize on the cob by 31 of sample households (23\%). Polyethylene, polypropylene and cotton sacks were reportedly used. Depending on the number of sacks, they were either stacked on the floor in an upright position or stacked on top of one another in the kitchen area or in an empty room. Sacks provided little protection against insects, especially borers and respondents complained that maize stored in this manner absorbed moisture from the floor (typically mud, sealed with cow dung or cement). Consequently, rotting occurred frequently.

Maize seed was stored by hanging cobs from the roof over the cooking area (open wood fire) by seven percent of sample households (Figure 3). Smoke fumigated the seed, preventing insect damage. Households that did not practice this method purchased seed annually.

\section{Maize storage efficiency}

The efficiency of storage systems was determined by two factors, namely storage length and incurred losses. Maize storage methods used by sample households were inefficient except for metal tanks (Table 3). The majority of sample households used the popular inqolobane (Table 2), despite a high incidence of maize losses during storage. Although storage lengths ranged from three to 24 months, the average storage length ranged from 5.6 to 8.6 months, indicating that grain is commonly consumed prior to or by the time the new season's maize is ready for harvesting. Maize storage has the potential to smooth food supply between harvests but seemingly insufficient produce is stored to see the households through to the next season. Sample households reported purchasing additional maize to tide them over to the next crop harvest, highlighting the inadequacy of production and/or storage systems. Sample respondents could not accurately estimate storage losses and so it is not possible to determine the proportion of maize lost due to deterioration in storage. However, a high proportion of respondents reported maize losses in storage (Table 3). It is therefore difficult to determine if food supply is constrained by inadequate production or if production is constrained by storage potential, and if storage potential is limited by maize deterioration. The following sections compare the efficiency of the storage methods on the assumption that production is not limited by storage and/or production capacity.

Inqolobane were comparatively cheap to construct and maintain and easily accessible to sample respondents, and therefore widely used. Although inqolobane can store grain for almost six months, the high incidence of maize losses makes this storage method inefficient. The maximum storage length for grain in metal tanks was twice that of inqolobane. The average storage length for inqolobane was also much lower than that of metal tanks. Thus, increased use of metal tanks could extend the availability of maize for households in the study districts. Furthermore, purchased insecticides were used in these tanks that resulted in lower post-harvest losses occurring. Therefore, metal tank storage may increase household food security but is less accessible to poorer households. The storage length of maize in sacks was almost comparable to the average storage length of maize in inqolobane. However, fewer households used sack storage and reported a lower incidence of maize losses in storage than respondents using inqolobane. No chemicals are added to grain in sacks or inqolobane, thus increasing storage losses.

Roof storage was primarily used for storing smaller quantities of maize seed. Maize cobs were hung over a fire where smoke fumigated the seed. Sample respondents pointed out that the smoke prevented the seed from spoiling and from pest infestation, but lamented that the quality of the maize seed stored in this way may be inferior, leading to low germination rates and lower yields. However, recent research on seed vigour shows that roof-stored seed had more vigour during germination than commercially available maize seed (Modi, 2003). There may be other factors influencing the respondents' opinion of the inferiority of this seed that warrants further research.

\section{Influence of maize storage on food security}

The relationship between the storage practices of sample households was tested against nine selected food security indicators (see Table 1 for the indicators selected) using Chi-square tests (Table 4). The directions of the statistically significant relationships were explored through cross-tabulation of the data. Six indicators were statistically significant, relating to the maize storage method used by sample households. Non-significant indicators of food security are not discussed further. The use of roof storage was not significantly related to any of the nine food security indicators, probably due to the small number of respondents who used this storage method, so roof storage of seed is not discussed further.

Total household asset value was significantly related to the use of inqolobane, metal tanks and sacks. Due to the accessibility, flexible size and affordability of 
TABLE 4: $\quad$ RESULTS OF CHI-SQUARE TESTS (P-VALUES) BETWEEN MAIZE STORAGE METHODS AND HOUSEHOLD FOOD SECURITY INDICATORS, NORTHERN KWAZULU-NATAL, $1999(\mathrm{~N}=134)$

\begin{tabular}{|c|c|c|c|c|}
\hline \multirow{3}{*}{$\begin{array}{l}\text { Storage method } \\
\text { Inqolobane } \\
\text { (traditional silos) }\end{array}$} & \multicolumn{2}{|l|}{ Significant P-values } & \multicolumn{2}{|c|}{ Non-significant P-values } \\
\hline & Household size & $0.034^{* *}$ & Household income & 0.818 \\
\hline & Household asset value & $0.011^{* *}$ & Food expenditure & 0.193 \\
\hline & Household head's education & $0.021^{\star \star}$ & Credit expenditure & 0.220 \\
\hline & Land used & $0.023^{\star *}$ & Household head's age & 0.547 \\
\hline & Livestock value & $0.001^{*}$ & & \\
\hline \multirow[t]{5}{*}{ Metal tanks } & Household asset value & $0.002^{*}$ & Household income & 0.367 \\
\hline & Household head's age & $0.047^{* *}$ & Credit expenditure & 0.358 \\
\hline & Household size & 0.008 * & Household head's education & 0.507 \\
\hline & Food expenditure & $0.094^{* \star *}$ & Livestock value $^{a}$ & \\
\hline & Land used & $0.054^{\star \star \star}$ & & \\
\hline \multirow[t]{6}{*}{ Sacks } & Household asset value & $0.002^{*}$ & Food expenditure & 0.501 \\
\hline & Livestock asset value & $0.036 * *$ & Credit expenditure & 0.473 \\
\hline & Household size & $0.015^{\star *}$ & Household head's age & 0.458 \\
\hline & & & Household head's education & 0.674 \\
\hline & & & Land used $^{\mathrm{a}}$ & \\
\hline & & & Household income $^{a}$ & \\
\hline
\end{tabular}

* =1 percent level of probability

$* *=5$ percent level of probability

$\star * *=10$ percent level of probability

${ }^{a}$ Cell frequencies were too small to carry out Chi square tests.

inqolobane, both relatively wealthier $^{3}$ and poorer households used inqolobane to store maize, despite its storage inefficiency. In addition, household food expenditure was significantly related to use of the costlier metal tanks, confirming that wealthier households were more likely to afford metal tanks than poorer households. Focus group discussions confirmed that cost constrained the use of metal tanks. Poorer households mostly used sacks for storing maize, as this re-used commercial packaging is readily available in such communities. Wealthier households diversified their storage practices by using the costlier metal tanks together with traditional silos to balance maize loss risks. Moreover, the few wealthier households who reported selling surplus maize did so at harvest time, averting storage losses.

The amount of land used for cultivation was significantly related to the use of metal tanks and inqolobane (Table 4). Larger cropping areas would likely lead to greater production, other factors such as irrigation and agricultural inputs being constant. This finding suggests that households with larger harvests diversify their storage practices to avert losses and

${ }^{3}$ The top percentile of households (with declared assets equal to or exceeding R20000) was regarded as wealthier households for this sample. balance the risk of loss. Metal tanks held considerable volumes, increased by the practice of storing the grain off the cob (unlike traditional methods where maize is stored on the cob), while the size of the annually constructed inqolobane is easily adjusted to accommodate the size of harvests.

Livestock value was also significantly related to the use of inqolobane and sack storage. Households with lower livestock values used these two forms of storage. This was not surprising as in many rural areas livestock is indicative of wealth. However, livestock ownership on its own may not necessarily reflect the wealth status of households accurately as some households may have invested in other capital items such as tractors, vehicles and/or other farm equipment. This may explain the non-significance of livestock to the use of metal tanks for storing maize.

Household size was significantly related to the use of inqolobane, metal tanks and sacks. Larger households used inqolobane and metal tanks as these storage methods have a relatively larger storage capacity, accommodating the requirements of larger households. The education level of the household head was significantly related only to the use of inqolobane. Almost half of respondent household heads using inqolobane had either no education or attended pri- 
mary school only. Sample households using the inqolobane were headed by less educated household heads who seemingly favoured more traditional storage systems. However, households with older household heads used metal tanks for storing maize. It was expected that households with older household heads would have favoured traditional storage methods, but seemingly older household heads had greater access to resources than households headed by younger members. Furthermore, households headed by older household members may have embraced the wisdom of diversified storage as a compromise against maize losses in storage.

\section{CONCLUSION}

The research findings showed that traditional storage methods used by sample households were not efficient. Over half the sample households used the popular inqolobane despite almost 86 percent of sample households reporting losses during storage. The inqolobane was comparatively cheap and easily accessible to sample respondents and is widely used on its own or combined with other storage methods to balance risks among storage systems. The improved efficiency of metal tanks could be attributed to their seals and the fact that insecticides were added to the grain, which was not the case of on-the-cob storage in inqolobane.

Rural households in northern KwaZulu-Natal lack appropriate crop storage technology. However, commercial storage systems are too costly and inappropriate for small and subsistence farmers. The lack of appropriate storage may be an underlying reason why sample farmers stored only maize.

The traditional inqolobane was the least efficient storage system used by the sample households. As inqolobane are inexpensive and relatively simple to construct, their construction and use should be improved to minimise maize losses. Metal tanks were more efficient, but a relatively costly storage system. Sack storage resulted in relatively moderate losses but storage space in homesteads was limited and the stored maize adsorbed moisture from the floor. Although losses were relatively low for roof-stored maize seed, households reported low yields from seeds stored in this manner.

Stored maize was largely used for domestic consumption although an unquantified, but reportedly small percentage was sold to local consumers. Although maize was stored, sample households purchased additional maize, possibly due to storage losses and inadequate production. Improved maize storage is urgently required to improve food security and provide storage potential for increased maize production. In addition, progressive production technologies should be investigated to improve yields and minimize production constraints.

\section{RECOMMENDATIONS}

It is recommended that the inqolobane structure be made more airtight or sheltered to minimise environmental hazards. Different construction materials (woven river reeds, sisal and/or grass) could also be used for a more airtight storage vessel, modeled on the woven basket structure or seshego used in the Limpopo Province. Insecticides (commercial and tested traditional types) could also improve maize quality in storage and extend the storage potential of inqolobane. Extension staff could provide training and guidance on the appropriate use of pesticides, including traditional and less costly pesticides such as aloe ashes. Farmers and extension services should explore bulk purchases of metal tanks and credit to finance bulk and communal facilities. In addition, the storage efficiency of metal tanks could be improved by inclusion of a simple 'tap' for accessing grain without having to break the seal on the tank's lid. The vigour of roof-stored seed should be further investigated to determine if this method of seed storage should be encouraged.

Although this study did not seek to determine the quality of stored seed and grain, food safety and consumer acceptance of stored products should be investigated to determine the role such grain plays in household food security and the potential for income opportunities through storing grain for sale later. Further investigation is also required to determine the role that stored maize plays in tiding households over periods of hunger due to its seasonal production and the effects of environmental hazards, such as droughts and floods.

\section{REFERENCES}

ALDERMAN, H. 1993. Obtaining useful data on household incomes from surveys. In von Braun, J \& Puetz, D. 1993. Data Needs for Developing Countries: New directions for household surveys. Washington, DC. International Food and Policy Research Institute. BONTI-ANKOMAH, S. 2001. Addressing food insecurity in South Africa. A paper presented at the South African Regional Poverty Network Conference on Land Reform and Poverty Alleviation in Southern Africa. 4-5 June, Pretoria.

FLORKOWSKI, J \& XI-LING W. 1990. Simulating the impact of pecan storage technology on farm price and grower's income. Southern Journal of Agricultural Economics 22(2):217-222.

HADDAD, L, KENNEDY, E \& SULLIVAN, J. 1994. Choice of indicators for food security and nutrition monitoring. Food Policy 19(3): 329-343.

KOHL, RL \& UHL, JN. 1998. Marketing of Agricultural Products. $\quad 8^{\text {th }}$ Edition. Upper Saddle River,New Jersey. Prentice-Hall.

LABADARIOS D. 2000. Executive Summary. National Food Consumption Survey in Children Aged 1 - 9 Years: South Africa 1999. Available on line. URL: ht t p://www.sahealthinfo.org/nutrition/ foodsummary.htm. Accessed 2 June 2003.

LINDBLAND, C \& DRUBEN, S. 1980. Small Farm 
Grain Storage: Storage methods 3. New York. Macmillan.

MAXWELL, S \& FRANKENBERGER, TR. 1996. Household Food Security Concepts, indicators and measurements: A Technical Review. Rome. International Fund for Agricultural Development.

MAXWELL, DG. 1996. Measuring food insecurity: The frequency of "coping strategies". Food Policy: 21 (3):291-303.

MODI, AT. 2003. Personal communication. Senior Lecturer in Crop Science, School of Agricultural Sciences and Agribusiness, University of Natal, Pietermaritzburg.

MUGHOGHO, MJK. 1989. Malawi: Food security issues and challenge for 1990's. In Rukuni M. 1989. Food Security Policies in the SADC Region. Harare. University of Zimbabwe and Michigan State University Food Security Research in Southern Africa Project. Department of Agricultural Economics and Extension.
NTLOKWANA, B. 1999. Personal communication. Senior Extension Officer, KwaZulu-Natal. Pietermaritzburg. Department of Agriculture and Environmental Affairs.

SALUNKE, DK \& DESAI, BB. 1986. Post-harvest Biotechnology of Oilseeds. Boca Raton, Florida. CRS Press.

TAKAVARASHA, T \& RUKOVO, A. 1989. Food security issues and challenges for the 1990's. In Rukuni M. 1989. Food Security Policies in the SADC Region. Harare. University of Zimbabwe and Michigan State University Food Security Research in Southern Africa Project. Department of Agricultural Economics and Extension.

WORLD BANK. 1986. The Challenge of Hunger in Africa: A call for action. Washington DC. International Bank for Reconstruction and Development and the World Bank. 